\title{
Seabird diet indicates changing Arctic marine communities in eastern Canada
}

\author{
J. F. Provencher ${ }^{1, *}$, A. J. Gaston ${ }^{2}$, P. D. O'Hara ${ }^{3}$, H. G. Gilchrist ${ }^{2}$ \\ ${ }^{1}$ Department of Biology, University of Victoria, Victoria, British Columbia V8W 3N5, Canada \\ ${ }^{2}$ Science and Technology Branch, National Wildlife Research Centre, Carleton University, Ottawa, Ontario K1A 0H3, Canada \\ ${ }^{3}$ Canadian Wildlife Service, Sidney, British Columbia V8L 4B2, Canada
}

\begin{abstract}
Changing climatic conditions are affecting ecosystems worldwide, but polar ecosystems are experiencing the most rapid changes as the extent of summer sea ice has diminished over the last several decades. In the Canadian Arctic, thick-billed murres Uria lomvia can be used as samplers of the marine environment, and we examined changes in the diet of the birds between recent and historical studies from the 1970s and 1980s. In the low Arctic, the amount of Arctic cod, an ice-dependent species, declined in the murre diet; and capelin, a subarctic species, has now become the primary prey item. In the mid-Arctic, where summer sea ice is still present during the summer, Arctic cod persists as an important prey item, but capelin is now regularly observed, marking an apparent northward expansion of this species over the last $30 \mathrm{yr}$. In the high Arctic, summer sea ice continues to dominate the seascape in most years, and Arctic cod continues to dominate the diets of the murres. Changes in Arctic cod in the bird diet were found to be more related to sea ice conditions averaged over multiple years rather than single-year indices, indicating that long-term changes in sea ice do impact this prey species. The diversity of the prey sampled by the birds has decreased, signaling a potential change in the number of prey species available. Overall, the birds illustrate changes occurring in the marine environment in areas where little other information is available.
\end{abstract}

KEY WORDS: Seabird - Arctic $\cdot$ Climate change $\cdot$ Diet shift $\cdot$ Fish community $\cdot$ Zooplankton · Thick-billed murre $\cdot$ Uria lomvia $\cdot$ Sea ice cover

Resale or republication not permitted without written consent of the publisher

\section{INTRODUCTION}

Changing climatic conditions are affecting biological systems worldwide (Edwards \& Richardson 2004). High latitudes are expected to be particularly affected by changing atmospheric and oceanographic conditions, as a result of widespread changes in sea ice and snow cover (IPCC 2007). In the Canadian Arctic, an overall warming trend and a reduction in summer sea-ice cover have been observed over the last several decades (Barber et al. 2008). Such changes are likely going to fundamentally alter Arctic ecosystems, as sea ice plays a central role to marine organisms, and changes in sea ice have direct impacts on local species (Gaston et al. 2005a, Soreide et al. 2010). Tracking changes in sea-ice ecosystems over time can help us understand ecosystem dynamics as well as how changing climatic conditions may affect the polar regions.

Seabirds are considered ideal organisms for tracking changes in marine environments (Cairns 1987). They are highly visible, easy to count, and have a life history that is tightly coupled with the environment, and as a result have been useful in studying changes in fish populations in a number of ocean basins (Piatt et al. 2007). In the eastern Canadian Arctic, the thick-billed murre Uria lomvia (hereinafter referred to as 'murre') has been shown to be a useful indicator species for tracking changes in the marine environment, based on long-term monitoring programs (Gaston et al. 2005b, 2009). 
Starting in the mid-1970s, several studies examined the diet of adult murres throughout Canada's low-, mid-, and high-Arctic oceanographic zones as defined by Salomonsen (1965) (Bradstreet 1980, Gaston \& Nettleship 1981, Gaston \& Noble 1985). Historically, the diet of high-Arctic murres was dominated by Arctic cod Boreogadus saida, a cold-water schooling fish that spawns on the under-surface of ice (Craig et al. 1982), while low-Arctic murres also consumed Arctic cod along with a number of secondary prey items (Gaston \& Bradstreet 1993).

Since these initial studies, several long-term monitoring programs have been established by Environment Canada in the Canadian Arctic to study murres, with a major part of the research focused on the murre colony at Coats Island, Nunavut $\left(62^{\circ} 57^{\prime} \mathrm{N}\right.$, $82^{\circ} 00^{\prime} \mathrm{W}$ ). In the $1980 \mathrm{~s}$ and early $1990 \mathrm{~s}$, most food items delivered to nestlings by parents on Coats Island were Arctic cod (Gaston et al. 2003). However, beginning in the mid-1990s, capelin Mallotus villosus, a subarctic schooling fish species common off the coast of Atlantic Canada, became more common in the nestling diet, whereas the amount of Arctic cod declined. By 1997, capelin was the most common prey item delivered to nestlings (Gaston et al. 2003), a pattern that has persisted to date (A. J. Gaston unpubl. data).

In light of the changes observed in the nestling diet at Coats Island, and the changes in sea ice observed throughout the eastern Canadian Arctic, a reassessment of adult murre diet throughout the region was needed to detect potential widespread changes in murre diets. In the present study, in order to compare current murre diets with historical samples, murres were collected for stomach content analysis from 2007 to 2009 (International Polar Year) in the same areas and on similar dates as collections made in the 1970s and 1980s (see Table 1).

As sea ice conditions are a major factor structuring marine ecosystems in the Arctic, the diets of the birds were expected to show the greatest changes in the low Arctic, where dramatic changes have occurred in summer sea-ice cover over the last few decades (Barber et al. 2008). Diversity in prey items at the lowArctic sites was expected to increase as subarctic species start to contribute more to the diversity of the murre diet. In the high Arctic, where sea ice continues to be present for much of the summer, murre diets were expected to show little or no change in composition or diversity, while in the mid-Arctic, changes were expected to be intermediate between those in the high- and low-Arctic zones (Gaston \& Bradstreet 1993).
We also looked at how changes in the 2 main prey species, Arctic cod and capelin, in the murre diet were related to changes in local sea-ice conditions during the breeding season in the year of sampling and in the previous 2 yr. Due to the sympagic (iceassociated) nature of Arctic cod, changes in this fish species in the diet of the murres was expected to be more positively related to sea ice over several years as compared with any single year of ice cover. Conversely, as capelin is a subarctic species, and not dependent on sea ice, the presence of this species in the murre diet was expected to be more negatively related to sea ice cover over a period of several years.

\section{MATERIALS AND METHODS}

Stomach content analysis has limitations as a dietary study tool, as it is biased toward prey items with hard parts or those that have been recently ingested (Jackson \& Ryan 1986). The retention time of prey items varies with species, and stomach contents usually reflect species preyed upon in the last 6 to $24 \mathrm{~h}$ (Brekke \& Gabrielsen 1994, Hawkins et al. 1997). As a result, direct dietary comparisons are admissible only where they duplicate, as closely as possible, the methods of the earlier studies.

\section{Collections}

Adult murres were collected at 5 sites spread throughout the eastern Canadian Arctic. Birds were shot with a 12-gauge shotgun using steel shot from a small boat in areas where birds were seen to be actively feeding. During the 2007-09 breeding seasons, murres were collected from the waters around Akpatok Island $\left(60^{\circ} 25^{\prime} \mathrm{N}, 68^{\circ} 08^{\prime} \mathrm{W}\right)$, Coats Island, and Digges Sound $\left(62^{\circ} 33^{\prime} \mathrm{N}, 77^{\circ} 35^{\prime} \mathrm{W}\right)$ in the low Arctic; the Minarets (also known as Akpait; $66^{\circ} 56^{\prime} \mathrm{N}$, $\left.61^{\circ} 46^{\prime} \mathrm{W}\right)$ in the mid-Arctic; and Prince Leopold Island $\left(74^{\circ} 02^{\prime} \mathrm{N}, 90^{\circ} 00^{\prime} \mathrm{W}\right.$ ) in the high Arctic (Fig. 1, Table 1). Murres were collected as close as possible to historical collection dates to minimize differences in diet due to seasonal patterns. After the collections were complete, carcasses were kept cool for 6 to $24 \mathrm{~h}$, and then frozen until dissections were carried out.

\section{Laboratory procedures}

Each gastrointestinal tract (GIT) was cut longitudinally along the entire length of the tract. Once the 


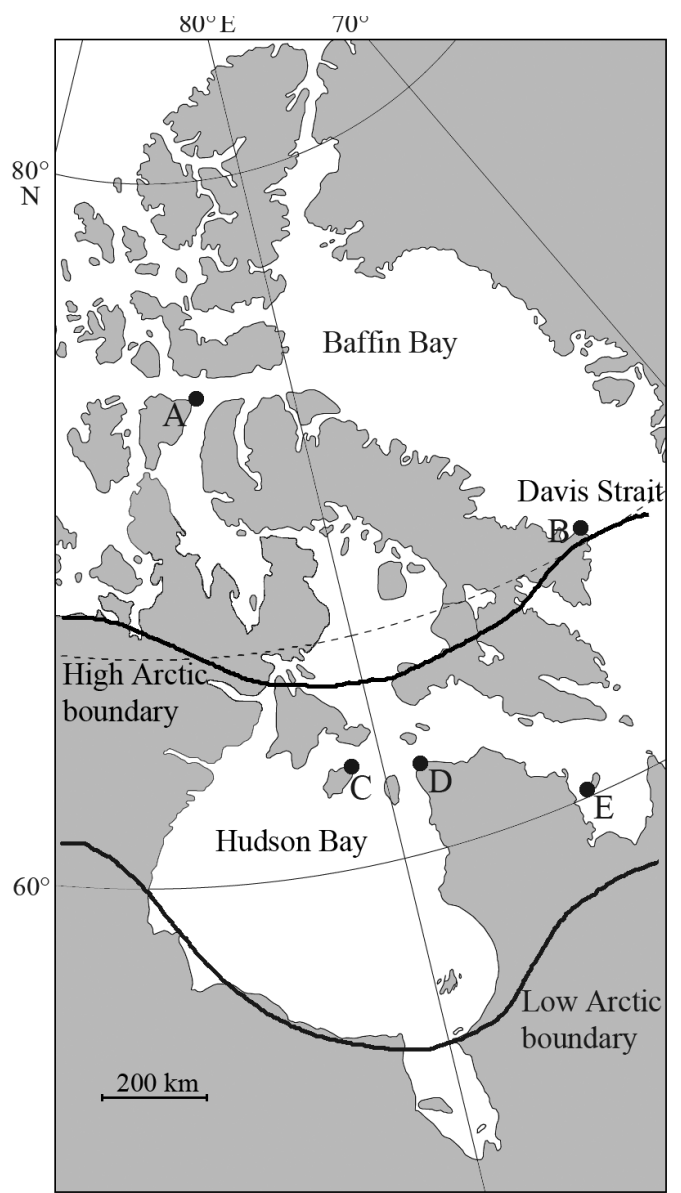

Fig. 1. Uria lomvia. Location of collections in the eastern Canadian Arctic in the 1970s-80s and 2007-09 and the boundaries of the low- and high-Arctic zones as described by Salomonsen (1965). The mid-Arctic zone is the area at the boundary between the low- and high-Arctic zones. A: Prince Leopold Island; B: the Minarets; C: Coats Island; D: Digges Sound; E: Akpatok Island
GIT was opened, the stomach was flushed with ethanol to remove all the items, taking care to remove all items in the folds of the stomach, and placed in 95\% ethanol. Prey remains in each stomach sample were sorted, divided into smaller vials, and categorized using an MZ6 Leica binocular microscope.

Otoliths were viewed, measured, and photographed using the Leica microscope, a scope-mounted video camera, and image analysis software. All otoliths were identified using Campana (2004), and voucher otoliths were sent to Otolith Technologies' laboratory in Stillwater, Nova Scotia for confirmation of identification (www.marinebiodiversity.ca/otolith/english/ home.htm). If 2 otoliths from a given stomach measured within $0.2 \mathrm{~mm}$, they were considered to originate from the same fish (Bradstreet 1980). The minimum number of fish in each stomach was calculated as the number of matched otolith pairs plus the number of unmatched individual otoliths.

Intact zooplankton individuals, along with heads and tails for each taxon, were enumerated and identified to the lowest taxonomic level possible (Holmquist 1959, Clarke 1962, Tencati \& Leung 1970, Baker et al. 1990, Klekowski \& Weslawski 1991, Vinogradov et al. 1996, Audzijonyte \& Vainola 2007). Abundance estimates were based on the sum of whole zooplankton and the number of heads or tails, whichever was more numerous, giving a minimum number for each stomach.

Polychaete jaws were identified as left or right, and the number of individual polychaetes present was determined from the maximum number of either right or left jaws. Squid numbers were estimated by the maximum number of beak hoods or rostrums present.
Table 1. Collections: Historic and current collections of thick-billed murres for dietary studies in the eastern Canadian Arctic

\begin{tabular}{|lccll|}
\hline Colony & Collection date & Year & $\mathrm{n}$ & \multicolumn{1}{c|}{ Source } \\
\hline Low Arctic & & & & \\
Akpatok Island & August 7 & 1983 & 19 & Gaston \& Bradstreet (1993) \\
Akpatok Island & August 19 & 2008 & 31 & Present study \\
Coats Island & July 27 & 2007 & 25 & Present study \\
Digges Sound & July-August & 1980 & 98 & Gaston et al. (1985) \\
Digges Sound & July-August & 1981 & 44 & Gaston et al. (1985) \\
Digges Sound & June-August & 1982 & 55 & Gaston et al. (1985) \\
Digges Sound & August 11 & 2008 & 30 & Present study \\
Digges Sound & July 28, August 1 & 2009 & 61 & Present study \\
Mid Arctic & & & & \\
The Minarets & late July & 1985 & 17 & Gaston \& Smith (1985) \\
The Minarets & August 5 & 2007 & 30 & Present study \\
The Minarets & August 3 & 2008 & 20 & Present study \\
High Arctic & & & & \\
Prince Leopold Island & June-August & 1976 & 48 & Gaston \& Nettleship (1981) \\
Prince Leopold Island & June-August & 1977 & 48 & Gaston \& Nettleship (1981) \\
Prince Leopold Island June 5, August 9 & 2008 & 50 & Present study \\
\hline
\end{tabular}

\section{Diet data analysis}

Sampling occurred at 5 colonies, but for dietary comparisons, only Digges Sound, the Minarets, and Prince Leopold Island are included, as these had both robust historic and current stomach samples. The 2007-08 dietary results for Coats Island and Akpatok Island are included and referred to for general discussion purposes, but due to a lack of historic stomach-contents data from Coats Island, and highly degraded current samples from Akpatok Island because of logistical challenges 
during collections, these colonies are not included in the diet-change analysis. The prey item results are presented as percent totals, which describe the proportion of prey items as a function of the total amount of prey items found in the birds at a given colony (see Fig. 2). Percent occurrence or incidence rate is given in the supplement (www.int-res.com/articles/suppl/ m454p171_supp.pdf), describing the proportion of birds that contained at least one of the prey items as a function of the total number of birds collected during the sampling (i.e. incidence rate).

To test for differences in the proportion of fish and invertebrates consumed by the birds as a function of total prey items, a generalized linear mixed model was used ('Proc GLIMMIX': this and other procedures run in SAS version 9.2). Fish proportion of total prey consumed was modeled with time period (historic vs. new) and zone (low, mid-, and high Arctic) as explanatory variables. The effect of year nested within sampling periods was modeled as a random variable. Only those birds sampled during the chickrearing season (July to mid-August) were included in this analysis to control for any seasonal difference in diet. The model was fitted with a binomial distribution and a logit function, and controlled for overdispersion of the data by modeling residuals as a random variable ('random $=$ residual' statement).

Counts within fish subgroups (e.g. Arctic cod, sandlance, sculpin) were modeled as response variables and tested for variation with time period and Arctic zone using a similar generalized linear mixed model. Again, the effect of year nested within time periods was modeled as a random variable. This model was fitted with a negative binomial distribution and log link function to control for over-dispersion in the data. Models failed to converge for capelin, sandlance, and the remaining fish categories pooled into a single category ('other') because of low occurrence in diets sampled in the high-Arctic zone, and for this reason we modeled these groups based on data from the lowand mid-Arctic zones only. When a significant interaction was found between time period and zone in the number of individuals within a fish category in the diet samples, LSMEANS statements were used for post hoc comparisons of fixed effects within this model.

The invertebrate diet data (hyperiids, gammarids, mysids, squid, other) were highly zero-inflated and over-dispersed, precluding the use of generalized linear mixed models. Instead, these data were modeled using maximum likelihood estimation ('Proc GENMOD') and a negative binomial distribution with a log link function. This modeling technique does not allow for the inclusion of year nested within time sample period as a random variable. When a significant interaction was found between time period and zone in the number of individuals within an invertebrate subgroup in the diet samples, LSMEANS statements were used for post hoc comparisons of fixed effects within this model.

\section{Sea ice analysis}

To examine the relationship between the sea ice and the main fish species found in the murres, we used the historical percentage of sea ice cover on 16 July from the area around the colonies as reported from the Canadian Sea Ice Service (using IceGraph 1.03, available at http://ice-glaces.ec.gc.ca/IceGraph 103/?id=11874\&lang=eng) as a linear explanatory variable for predicting diet composition in the murres. Sea ice on this date has been shown to be related to murre diet (Gaston et al. 2005b). These analyses were more complicated than comparing diet composition between sampling periods because prey populations are likely determined by ice conditions in previous years. For this reason, indices of ice conditions at variable lag-times were created as predictors for diet composition among the 3 Arctic zones. Indices of ice conditions used were conditions during the sample year $\left(t_{0}\right)$, the year before sample $\left(t_{-1}\right)$, and $2 \mathrm{yr}$ before sample $\left(t_{-2}\right)$, as well as mean indices combining sample year and the year prior to sample, $\left(t_{0}+\right.$ $\left.t_{-1}\right) / 2$, and mean combining sample year, year prior to sample, and 2 yr prior to sample, $\left(t_{0}+t_{-1}+t_{-2}\right) / 3$.

To explore the relationship between the proportion of fish in overall diet and subgroup abundance with the various ice condition indices, we used maximum likelihood estimation and the Akaike information criterion (AIC) to guide our choice among the different indices. For the analysis based on fish proportion, we modeled with a logit link function and binary distribution for proportion of fish, and for both analyses based on the fish subgroup abundance data, we used a log link function and negative binomial distribution to account for over-dispersion within the data. All exploratory models included zone and interactions as explanatory parameters.

Once the best-fit ice index was determined for both proportion of fish in overall diet and fish subgroup abundance, we tested the relationship between the best-fit ice condition index with proportion of fish and subgroup abundance in diet samples among zones, again using 'Proc GENMOD' with logit link function and a binary distribution (proportion data), and with a log link function and a negative binomial distribution 
to correct for over-dispersion in the subgroup abundance data. Insignificant explanatory variables and higher-order variables were removed in the final model.

\section{Prey diversity}

Prey diversity for each site was examined using species-richness accumulation curves, which allow for standardized comparison of diversity across collections that differ in sample size (Gotelli \& Colwell 2001). This approach was used to examine prey species diversity in murre diets at the 3 colonies with robust historic and current diet sampling (Digges Sound, the Minarets, and Prince Leopold Island). All birds sampled in July and August (the chick-rearing period) that contained at least 1 identified item in their GIT (leading to smaller sample sizes) were grouped together by colony and sampling period, and the prey abundances for each bird were put into a matrix in EcoSim (Gotelli \& Entsminger 2009) to create a sample-based curve, with a rarefaction curve as the randomization algorithm and species richness as the prey species diversity index. Prey diversity curves were then produced in Excel in order to compare the species richness with $95 \%$ confidence intervals. Non-overlapping endpoints outside of $95 \%$ confidence interval curves indicate significantly different diversity levels.

\section{RESULTS}

During 2007-09, 247 GITs were examined, of which 191 were from Digges Sound, the Minarets, and Prince Leopold Island, compared with 331 from the 1970s and 1980s from the same sites (Gaston \& Bradstreet 1993). In the present study, 12488 prey items were identified (Tables S1 \& S2 in the supplement at www.int-res.com/articles/suppl/m454p171_ supp.pdf), with fish accounting for $21 \%$ of the total number of prey items and invertebrates making up the rest. Most GITs contained $>1$ type of prey and only 14 (5.6\%) contained no identifiable prey remains.

\section{Differences among colonies}

The primary prey items identified varied among the 5 colonies sampled. At Prince Leopold Island, Arctic cod was predominant (Fig. 2); at the Minarets, it was Arctic cod and mysids, with other fish and invertebrates in smaller numbers; at Coats Island, hyperiid

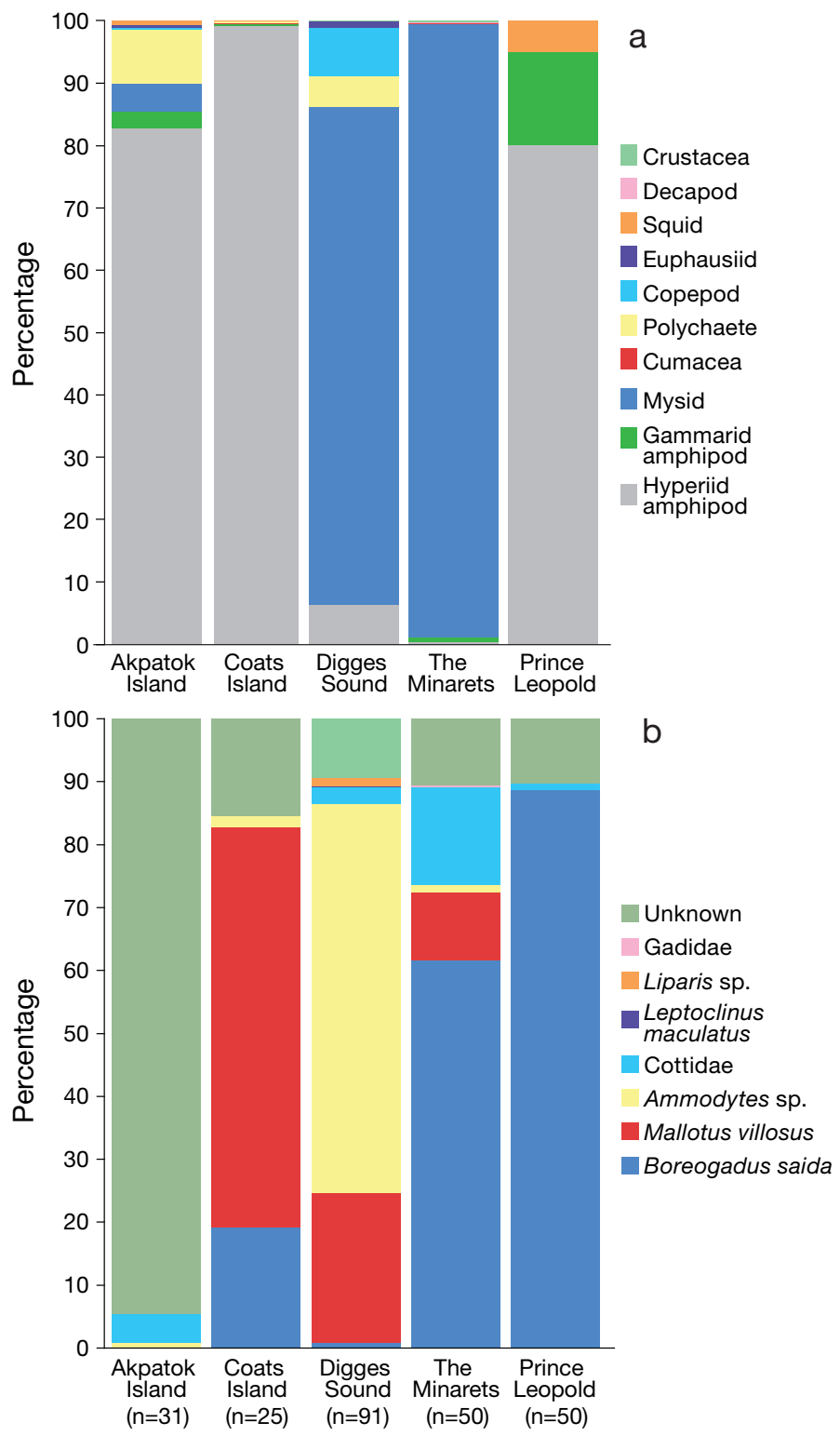

Fig. 2. Uria lomvia. Percent totals of (a) invertebrate and (b) fish prey items from eastern Canadian Arctic samples in 2007-09. Akpatok Island ( $\mathrm{n}=31$ ), Coats Island $(\mathrm{n}=25)$, and Digges Sound ( $\mathrm{n}=91$ ) are in the low Arctic; the Minarets $(\mathrm{n}=50)$ is in the mid-Arctic; and Prince Leopold Island $(\mathrm{n}=50)$ is in the high Arctic

amphipods were the most numerous prey item, with capelin the most numerous fish; and at Digges Sound, sandlance and capelin were the most common fish and mysids the most abundant invertebrates. At Akpatok Island, the stomach contents were highly degraded due to an unexpected delay in preserving the birds, resulting in many of the otoliths not being identifiable. Hence most of the fish in the diet are unknown, but by numbers, hyperiid amphipods were the largest group of invertebrates consumed at Akpatok. 


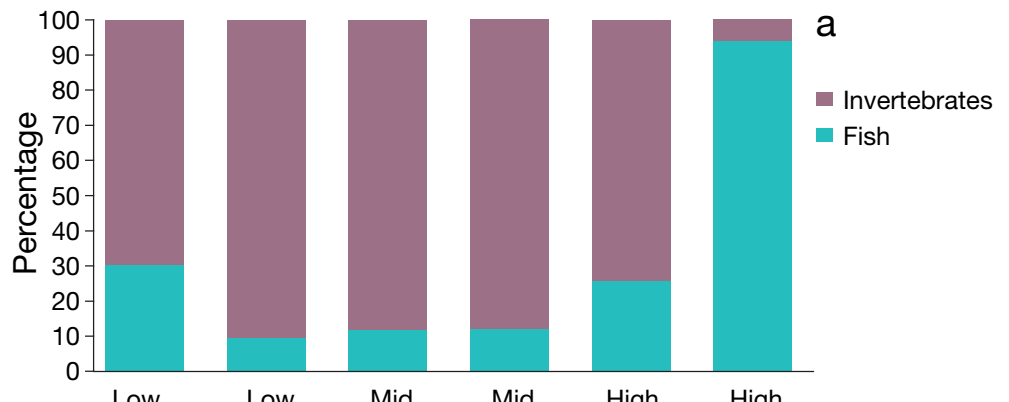

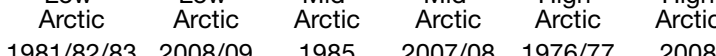

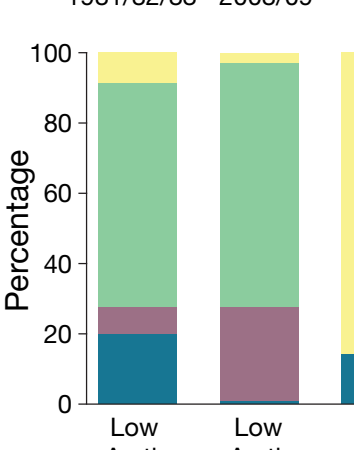

Arctic Arctic

1981/82/83 2008/09

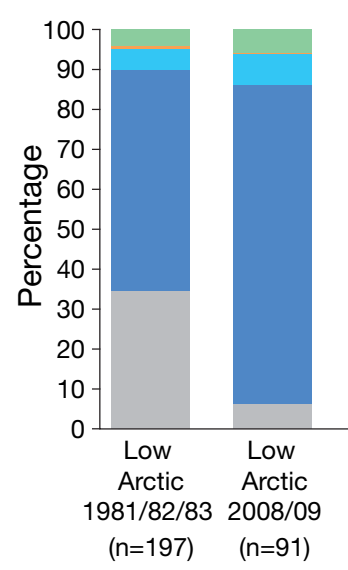

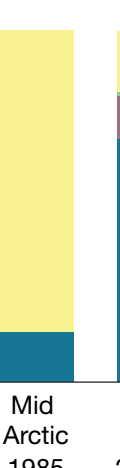

1985
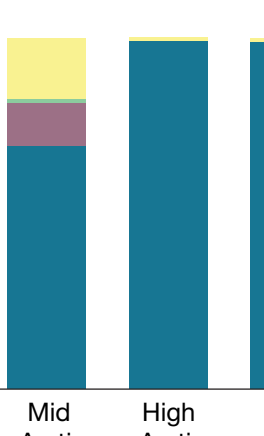

Arctic Arctic Arctic

2007/08 1976/77 2008

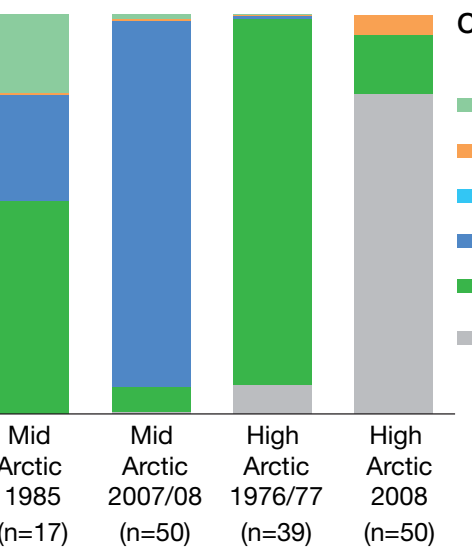

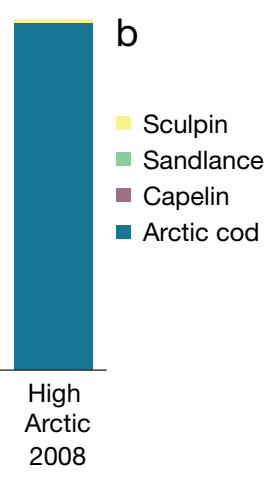

C

Other

Squid

- Copepod

- Mysid

Gammarid amphipods

- Hyperid amphipods

have increased (old proportion: $0.43 \pm 0.30$; new proportion: $0.98 \pm 0.05$ ) but we failed to detect significance $(t=1.56, \mathrm{df}=376, \mathrm{p}=0.12)$.

Fish species abundance varied between time periods differently among the 3 Arctic zones for the 2 fish species with sufficient data to test (Arctic cod, sculpin). The proportion of Arctic cod differed significantly between time periods and among zones $\left(F_{2,304}=6.91, p=0.0012\right)$. In the low Arctic, there was a significant decrease in the proportion of Arctic cod in the diet from $30 \%$ of the fish consumed to $<5 \%(t=-2.85, \mathrm{df}=304$, $\mathrm{p}=0.005)$. In the mid-Arctic, Arctic cod increased from $15 \%$ of the fish consumed in 1985 to almost $70 \%(t=2.02, \mathrm{df}=304, \mathrm{p}=0.04)$ in the 2007-08 sample. In the high Arctic, Arctic cod continued to be the main fish prey species $(t=$ $0.97, \mathrm{df}=304, \mathrm{p}=0.33$ ). Sculpins (family Cottidae) did not show a significant change over time $\left(F_{1,5}=0.81, \mathrm{p}=0.41\right)$.

Analyses based on capelin, sandlance, and 'other' fish data were restricted to murres sampled in the low- and mid-Arctic zones only, because of an extremely low rate of occurrence for these species in samples from the high Arctic. The number of capelin found in murre diets increased with time $\left(\chi_{1,265}^{2}=17.8, p<0.0001\right)$ in both zones $\left(\chi_{1,264}^{2}=3.34, \mathrm{p}=0.07\right)$, from 0 to $12 \%$ in the mid-Arctic and from 8 to almost $30 \%$ in the low Arctic zone. A change in sandlance Ammodytes sp. abundance was not detected between time periods $\left(\chi_{1,264}^{2}=1.23, p=0.27\right)$ or time periods and zones $\left(\chi^{2}{ }_{1,265}=0.03, \mathrm{p}=0.86\right)$. There were no significant changes in analyses based on data pooled among the remaining fish species ('other'), likely because of small sample size.
Fig. 3. Uria lomvia. Historic and current diet samples in the low Arctic (Digges Sound), mid-Arctic (the Minarets), and high Arctic (Prince Leopold Island). Percent total of (a) fish and invertebrates, (b) identified fish species, and (c) invertebrate prey items

\section{Differences in prey composition between recent and earlier samples}

Overall, fish proportion (mean $\pm \mathrm{SD}$ ) varied between sampling periods inconsistently among zones (Fig. 3; $F_{2,376}=3.46, \mathrm{p}=0.032$ ). In particular, the proportion of fish decreased in the low-Arctic zone (historic: $0.40 \pm 0.18$; new: $0.055 \pm 0.045 ; t=2.11$, df $=376, \mathrm{p}=$ $0.036)$, did not change in the mid-Arctic zone $(t=$ 0.09, $\mathrm{p}=0.93$ ), and in the high-Arctic zone it may
Table 2. Uria lomvia. Summary of changes in prey items sampled in the 1970s-80s and 2007-09 diets in the low Arctic (Digges Sound), mid-Arctic (the Minarets), and high Arctic (Prince Leopold Island) based on significant changes in prey abundance. Only those prey items that showed a significant interaction over time are shown. ' $\uparrow$ ' denotes an increase, ' $\downarrow$ ' denotes a decrease, ' $=$ ' denotes no change, and 'na' denotes not able to test

\begin{tabular}{|c|c|c|c|}
\hline & Low Arctic & Mid-Arctic & High Arctic \\
\hline Fish & $\downarrow$ & $=$ & $=$ \\
\hline Arctic cod & $\downarrow$ & $\uparrow$ & $=$ \\
\hline Capelin & $\uparrow$ & $\uparrow$ & na \\
\hline \multicolumn{4}{|l|}{ Mysids } \\
\hline Hyperiid amphipods & $\downarrow$ & $\uparrow$ & $=$ \\
\hline Gammarid amphipods & $\downarrow$ & $\downarrow$ & $\downarrow$ \\
\hline
\end{tabular}


Overall invertebrates in the diet of the murres also changed over time (Fig. $3 ; \chi^{2}=22.3, \mathrm{df}=5, \mathrm{p}=$ 0.0005). Both copepod and squid abundance in murre diet did not vary with time (copepod: $\chi^{2}=3.38$, $\mathrm{df}=1, \mathrm{p}=0.070$; squid: $\chi^{2}=1.51, \mathrm{df}=1, \mathrm{p}=0.22$ ) and did not vary with time period by zone interaction (copepod: $\chi^{2}=0.98, \mathrm{df}=2, \mathrm{p}=0.61$; squid: $\chi^{2}=3.65$, $\mathrm{df}=2, \mathrm{p}=0.16)$. Gammarid amphipods decreased significantly with time period $\left(\chi^{2}=23.8, \mathrm{df}=2, \mathrm{p}<\right.$ $0.0001)$ consistently among zones $\left(\chi^{2}=2.85, \mathrm{df}=2, \mathrm{p}\right.$ $=0.24)$. Mysids also decreased significantly with time $\left(\chi^{2}=8.11, \mathrm{df}=1, \mathrm{p}=0.0014\right)$ consistently among zones $\left(\chi^{2}=1.35\right.$, df $\left.=2, p=0.51\right)$.

The amount of hyperiid amphipods in the diets of the murres varied inconsistently with time among the zones $\left(\chi^{2}=16.8, \mathrm{df}=2, \mathrm{p}=0.0002\right)$. In the low Arctic, where hyperiid amphipods formed a relatively large portion of the murre diet in the earlier period, there was a significant decrease (from $30 \%$ of invertebrates to $8 \%: \chi^{2}=20.48, \mathrm{df}=1, \mathrm{p}<0.0001$ ). In the mid-Arctic, hyperiids contributed a small amount to the bird's diet but showed a significant increase with time $\left(\chi^{2}=6498.3, \mathrm{df}=1, \mathrm{p}<0.0001\right)$ (Fig. 3). In the high Arctic, hyperiid amphipods continued to contribute to the diet of the birds in very small numbers, with only 14 hyperiids found in 50 birds from the high Arctic in $2008\left(\chi^{2}=2.91\right.$, df $\left.=1, p=0.09\right)$.

Other invertebrate prey items found in small numbers include annelids, cumaceans, decapods, and euphausiids. Grouped together, these prey items were found to account for $<10 \%$ of total invertebrate prey items, except at the Minarets in 1985, where $>20 \%$ of the invertebrates were from these 4 groups. Independently, changes in these groups could not be modeled due to limited numbers in the samples.

Considering all of the above changes, the greatest amount of change occurred in the diet of the murres in the low Arctic, with fewer changes in the midArctic and the least amount of changes in the high Arctic (Table 2).

\section{Changes in ice conditions}

Between 1971 and 2010, the sea ice cover in northern Hudson Bay, around Digges Sound (low Arctic), decreased strongly, especially after 1993 (Fig. 4). On average, the extent on 16 July was $33 \%$ during the period 1971 to 1993 and only $7 \%$ after 1993, and the overall slope of the trend line for sea ice cover (mean $\pm \mathrm{SD}$ ) for this time period is $-7.45 \pm 5.13 \%$ decade $^{-1}$, suggesting a long-term decrease in sea ice. In Davis Strait (mid-Arctic), summer sea ice showed only a

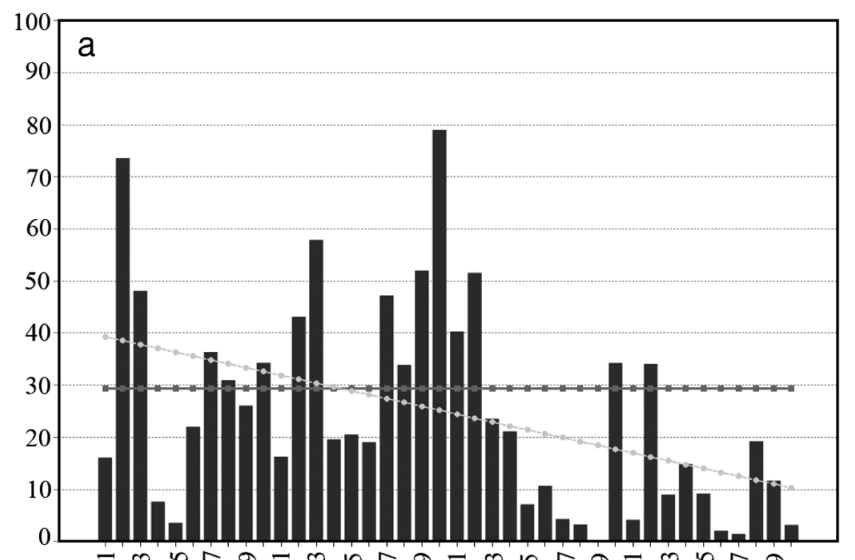

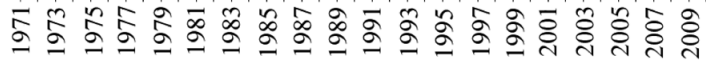
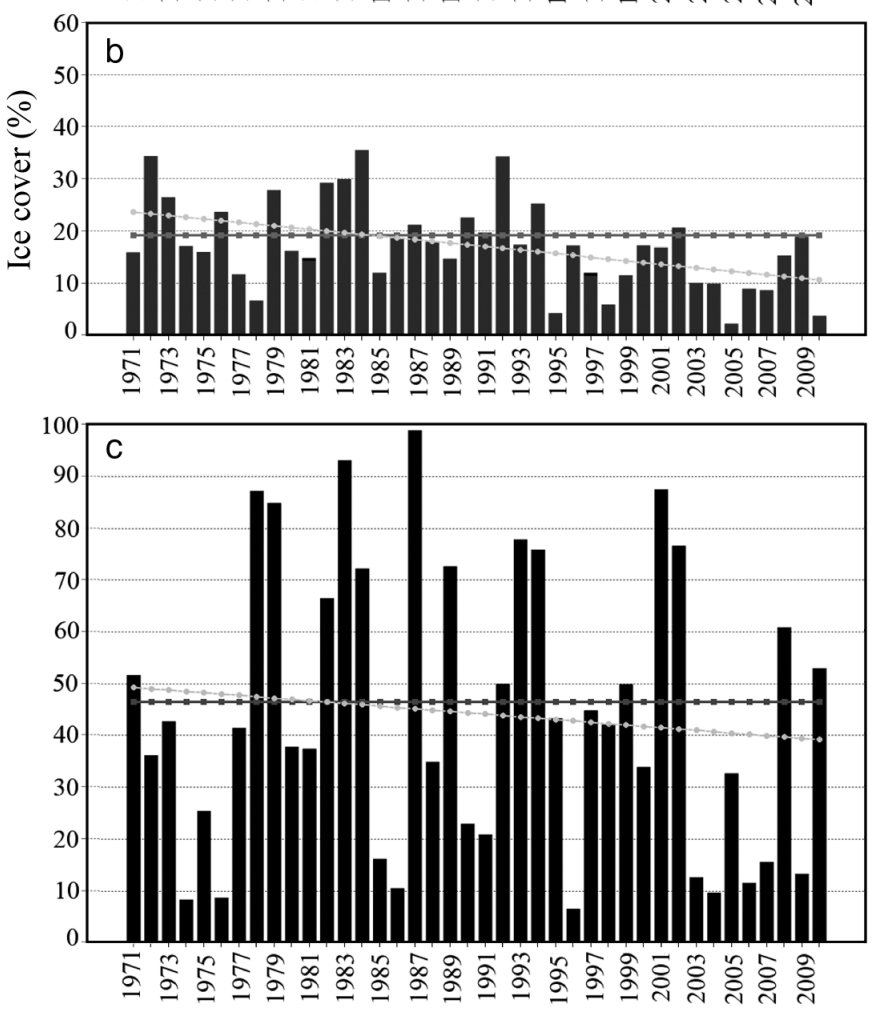

Fig. 4. Uria lomvia. Sea ice cover in the eastern Canadian Arctic during the chick-rearing period from 1971 to 2010 on 16 July of each year in (a) North Hudson Bay Narrows (low Arctic; slope: $-7.45 \pm 5.13 \%$ decade $^{-1}$ ), (b) Davis Strait (midArctic; slope: $-3.36 \pm 2.11 \%$ decade $^{-1}$ ), (c) Lancaster Sound (high Arctic; slope: $-2.60 \pm 7.49 \%$ decade $^{-1}$ ). The dark gray line indicates the average ice cover and the light gray indicates the overall trend in sea ice cover between 1971 and 2010. The slopes listed above are for the trend line for each region

small decline in sea ice over the last $40 \mathrm{yr}$ (slope: $-3.36 \pm 2.11 \%$ decade $^{-1}$ ), and in Lancaster Sound (high Arctic), sea ice cover showed substantial fluctuations and no strong trend (slope: $-2.60 \pm 7.49 \%$ decade $^{-1}$ ) between 1971 and 2010. 
Table 3. Uria lomvia. Model fit (Akaike information criterion) for various ice indices explaining variation in the proportion of fish in the diet and variation in abundance of Arctic cod and capelin in the diet. Bold text indicates the best fit model of the 5 tested as shown

\begin{tabular}{|lccccc|}
\hline & $\begin{array}{c}\text { Sample year } \\
\left(t_{0}\right)\end{array}$ & $\begin{array}{c}1 \text { yr lag } \\
\left(t_{-1}\right)\end{array}$ & $\begin{array}{c}2 \text { yr lag } \\
\left(t_{-2}\right)\end{array}$ & $\begin{array}{c}2 \text { yr average } \\
\left(\left(t_{-1}+t_{0}\right) / 2\right)\end{array}$ & $\begin{array}{c}3 \text { yr average } \\
\left(\left(t_{-2}+t_{-1}+t_{0}\right) / 3\right)\end{array}$ \\
\hline Proportion of fish & 12215.2 & 13448 & $\mathbf{1 0 7 9 0 . 2}$ & 12789.5 & 11921.3 \\
Arctic cod & 1388.4 & 1327.3 & 1322.4 & 1363.8 & $\mathbf{1 3 1 9 . 6}$ \\
Capelin & 630.7 & 642 & $\mathbf{6 2 1 . 1}$ & 639.4 & 631 \\
\hline
\end{tabular}

mid-Arctic zone $(t=0.52, \mathrm{df}=$ $381, \mathrm{p}=0.60$ ), and there was significant variation in the high Arctic where the proportion of fish decreased with more ice cover $(t=-2.02, \mathrm{df}=381, \mathrm{p}=0.044)$. Capelin abundance varied significantly with the same best-fit ice index as overall fish proportion (ice conditions $2 \mathrm{yr}$ prior to sample year $)\left(F_{1,370}=26.6, \mathrm{p} \leq\right.$ 0.0001 ), but this variation was

Changes in local sea-ice conditions were significantly associated with changes in the proportion of fish in general and specifically with the 2 main fish prey species consumed by murres, Arctic cod and capelin, but the nature of this association varied among zones. The ice index reflecting ice conditions 2 yr prior to the sample year had the highest explanatory power for variation in the proportion of fish in murre diets (Table 3), the ice index reflecting ice conditions averaged over $3 \mathrm{yr}$ up to and including the sample year was most effective for explaining variation in Arctic-cod abundance, and ice conditions prior to the sample year best predicted capelin abundance in murre diets.

Proportion of fish in the diet varied significantly with the best-fit ice index reflecting ice conditions $2 \mathrm{yr}$ prior to sample year $\left(F_{2,381}=9.45, \mathrm{p} \leq 0.0001\right)$, and most of this variation occurred in the low-Arctic zone where fish proportion decreased significantly with the decrease in sea ice $(t=8.46, \mathrm{df}=381, \mathrm{p} \leq$ 0.0001). There was no significant relationship in the

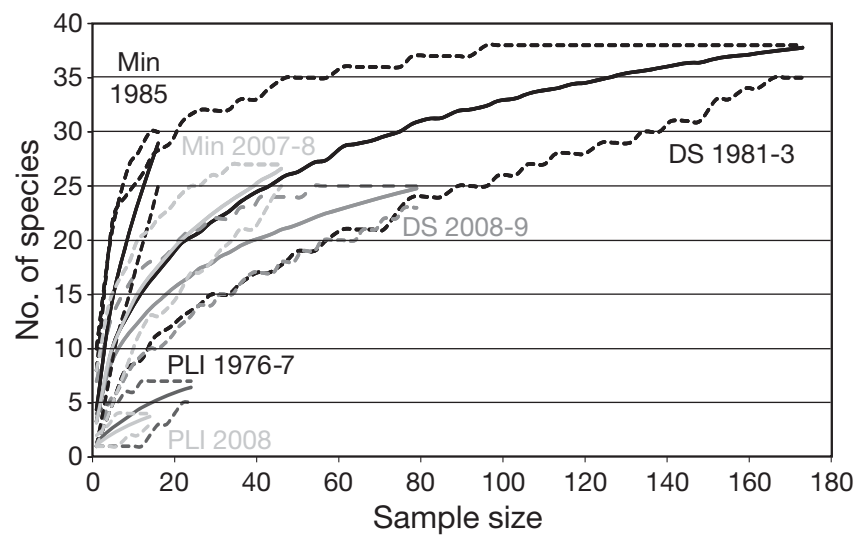

Fig. 5. Uria lomvia. Prey species richness curves (sample size vs. number of species) for diets compared between sampling in the 1970s-80s and again in the same locations in 2007-09 at Digges Sound (DS; 1981-83 black, 2008-09 mid-gray), the Minarets (Min; 1985 black, 2007-08 light gray), and Prince Leopold Island (PLI; 1976-77 dark gray, 2008 light gray). Dotted lines: $95 \%$ CIs consistent among Arctic zones for this species. Arctic cod abundance in the diet varied with the best-fit ice index averaged over the previous 3 yr including the sample year, and the nature of the relationship differed significantly among Arctic zones $\left(F_{2,368}=\right.$ 45.8, $\mathrm{p} \leq$ 0.0001). In the high Arctic, no significant change was detected in Arctic cod consumed by murres as the local ice conditions changed $(t=0.16, \mathrm{df}=$ $368, \mathrm{p}=0.69)$, but in the low Arctic, Arctic cod increased in the murre diet with more sea ice $(t=$ $32.2, \mathrm{df}=368, \mathrm{p}=0.0001$ ), and in the mid-Arctic, Arctic cod decreased with increasing ice cover $(t=15.0$, $\mathrm{df}=368, \mathrm{p}=0.0001$ ).

\section{Changes in prey diversity}

Diet diversity did not change between time periods in either the low Arctic (Digges Sound; 1980s: mean = $37.8, \mathrm{n}=178 ; 2000 \mathrm{~s}$ : mean $=24.78, \mathrm{n}=81$ ) or high Arctic (Prince Leopold Island; 1970s: mean $=3.73, \mathrm{n}=16$; 2008: mean $=6.42, \mathrm{n}=29$ ), with $95 \%$ confidence intervals overlapping in both cases (Fig. 5). Diversity did differ significantly in the mid-Arctic (the Minarets; 1985: mean $=28.94, \mathrm{n}=48 ;$ 2007-08: mean $=26.60, \mathrm{n}$ = 17) as indicated by the non-overlapping endpoints of the diversity curves (Fig. 5). Differences in diversity were not related to number of prey items, or associated with any single group of prey for any colony, and the level of taxonomic differentiation was similar among all samples.

\section{DISCUSSION}

\section{Changes in diet}

Changes in the diet of murres between earlier and recent samples were found in all zones. These changes are difficult to interpret as we have only 2 collection points separated by 20 to $30 \mathrm{yr}$, with little 
information from the intervening time. One potential confounding factor in diet comparisons is timing, as adult birds have been shown to alter their prey spectrum over the breeding season (Elliott et al. 2009), thus we tried to repeat as near to the original sampling dates as possible, which still correspond to the bird's breeding phenology. Fisheries may also influence prey communities, but no commercial fisheries operate in any of the areas sampled, so it is unlikely that our results are in any way affected by fisheries. Competition among other top predators can also influence marine communities, but although razorbills and subarctic gulls have increased in the low Arctic (Gaston \& Woo 2008), their numbers are negligible relative to the size of the large murre colonies (Brown et al. 1975, Gaston 1991). All these factors must be considered when examining and interpreting detectable changes in seabird diet, but their effects in the present study are likely to be small, allowing murres to be used as sentinels of changing marine ecosystems.

Arctic cod still dominates the diet of the highArctic murres. This supports our prediction that little change should have occurred in the diet of the highArctic murres as sea ice conditions, although variable, have shown no consistent trend or change during the murre's breeding season. Arctic cod was also still the main fish species in the murre diet in the mid-Arctic, where sea ice is also still present in the summer months. In the low Arctic, where summer sea ice has declined the most drastically, and is now rare or non-existent, Arctic cod has all but disappeared from recent murre diets. Very few Arctic cod were found in the recent sample from Digges Sound, and only slightly more in the birds from Coats Island. At Akpatok Island, where murre diet studies go back 6 decades, the recent sampling found no Arctic cod, whereas this species was found to be a main prey item fed to chicks in 1954 (Tuck \& Squires 1955) and was still present in the murre diet in 1983 (Gaston \& Bradstreet 1993). The decrease in Arctic cod in the murre diet is highly associated with ice conditions over 3 yr prior to and including the sample year in the low and mid-Arctic, suggesting that changes in this prey species in murre diets is more likely due to longer-term, chronic changes than episodic acute events.

The dependence of Arctic cod on sea ice (Craig et al. 1982), declining numbers of Arctic cod in murre diets in Digges Sound cumulatively related to sea ice changes, and the disappearance of Arctic cod from the diet of murres over the last half century at Akpatok Island indicate that changes in Arctic cod as a prey item in the low Arctic may be a consequence of changing sea-ice conditions over the long term. Given the decrease in Arctic cod observed in murre diets in the low Arctic, where summer sea ice is negligible or absent most years, and the variability of sea ice cover in the high Arctic, where Arctic cod continues to be the main food item, our results indicate that the presence or absence of sea ice is the largest factor in Arctic cod availability for murres, although percent cover is likely to be a contributing factor as well.

Alongside the decrease in Arctic cod, the increase in capelin in the diet of the murres sampled in 2007-08 in the low and mid-Arctic suggests that this subarctic fish is becoming an important prey item at these colonies. Capelin is an abundant item in seabird diets in Atlantic Canada (Davoren \& Montevecchi 2003), but before the mid-1990s it was only observed as a secondary prey item for murres in the low Arctic (Gaston \& Bradstreet 1993). Throughout the 1980 s to the mid-1990s, capelin was a secondary prey item in northern Hudson Bay (Gaston et al. 2003), an area within the described range of this species (Leim \& Scott 1966), but was not found among nestling diets at Hantzsch Island, off SE Baffin Island (Gaston \& Noble 1985), an area just north of the described distribution of capelin at the time. While capelin was present in the low Arctic prior to the 1980s, no range maps for capelin extended north to the Arctic Archipelago, no records existed for capelin on Baffin Island, and no capelin were found in the diets of the mid-Arctic adults at the Minarets in 1985 (Tee-van 1948, Leim \& Scott 1966, Gaston \& Bradstreet 1993). Now, in 2007-09, capelin has become the dominant prey item at murre colonies in the low Arctic and is common at the Minarets in the mid-Arctic, which lies outside of the range described previously (Leim \& Scott 1966), but within more recent range descriptions (Muss et al. 1999), suggesting a northward expansion in the range of this prey species.

In Hudson Bay, the change in sea ice has not been linear, but showed a more step-wise change in the mid-1990s (Scott \& Marshall 2010, A. J. Gaston unpubl. data). The replacement of Arctic cod by capelin as the main constituent of food fed to nestling murres at Coats Island coincided with this decrease in sea ice in the low Arctic (Gaston et al. 2003). It is also important to note that prey stocks for murres are not likely to be solely determined by conditions in the year of collection, but as seen in our analysis can be affected by conditions over several years prior to sampling. Thus, a more thorough analysis of multi- 
year trends in sea ice may be more important to prey fauna availability than ice conditions in any particular year.

The decrease in Arctic cod in the diet with the simultaneous increase in capelin could be interpreted as a switch in preference by the murres, rather than a decrease in Arctic-cod numbers. However, this appears unlikely, because of the decline in the sea ice on which the Arctic cod depend, and because long-term monitoring from Coats Island suggests that during the period when the parents switched from Arctic cod to capelin for feeding their young, nestlings had reduced growth rates, indicating that this change in prey was not beneficial to the young (Gaston et al. 2005b).

Based on the increase of subarctic capelin at lowArctic sites over the last decade, an increase in subarctic invertebrates was also expected in the diet of the low-Arctic birds. On the contrary, no invertebrate species characteristic of subarctic waters were identified, indicating that no general northward movement of invertebrate species has occurred to date. As most invertebrates are zooplankton and depend on the currents for dispersal, while fish can move of their own accord, subarctic zooplankton may take longer than fish to expand northwards. As ice conditions change, southern zooplankton species may be more likely to appear in Davis Strait (the Minarets) rather than in Hudson Bay, due to the direction of prevailing currents (Rekacewicz \& Bournay 1998).

Some changes in invertebrates were observed. The proportion of hyperiid amphipods, previously mostly Themisto libellula, fell at Digges Sound. Where the cold-water hyperiid amphipods and Arctic cod used to dominate the diet in Digges Sound, now 2 subarctic fish species (capelin and sandlance) and mysids are the primary prey items, suggesting large-scale changes in the marine environment around this colony.

Several species of the ice-associated amphipod genus Onisimus (Horner et al. 1992), common in murre diets earlier (Gaston \& Bradstreet 1993), were present in diets at the Minarets in 2007-08, suggesting that summer sea ice continues to influence the organisms found in this area during the murre breeding season. At Prince Leopold Island, the birds sampled in 1976-77 contained a large number of Onisimus spp. (Gaston \& Nettleship 1981), but none was found in the recent samples. Sea ice is still present at Prince Leopold Island during the breeding season, and a number of the birds were collected while feeding among ice flows, so a decline in ice is not likely to account for the lack of Onisimus spp. amphipods in Lancaster Sound.

\section{Changes in diversity}

Contrary to our expectations, we found no evidence for an increase in species diversity in any of the 3 zones. The highest prey diversity in the historic samples was found at Digges Sound, but among the recent samples the highest diversity was found at the Minarets. However, at the latter colony, diversity was actually lower in 2007-08 than in 1985. As climatic conditions change, it has been predicted that highlatitude areas will likely be sensitive to changes in biodiversity (Cheung et al. 2009). Our results suggest that there has been no immediate effect on biodiversity with decreasing levels of summer sea ice, although much more comprehensive studies are needed.

\section{Changes in trophic levels}

The proportion of fish consumed by murres at lowand high-Arctic colonies was found to have significantly changed. Such changes may have caused a change in the overall trophic level of the murre diet since the last sampling period. The murres from the different colonies show a significantly different $\delta \mathrm{N}$ ratio in breast muscle tissue (J. F. Provencher \& A. J. Gaston unpubl. data), suggesting that within the species, trophic level differs among colonies. If current dietary patterns persist, they may lead to the high-Arctic (Prince Leopold Island) murres feeding at a higher trophic level and low-Arctic (Digges Sound) murres feeding at a lower trophic level than in the past. Braune (2009) found that the murres from Coats Island (low Arctic) have shown a decrease in $\delta \mathrm{N}$ ratio in eggs since the early 1990s, suggesting that a change in trophic position on a colony-wide scale has occurred over the last 2 decades. Although historical diet information is not available from Coats Island and no historical stable-isotope data are available from Digges Sound, the change in trophic level at Coats Island supports the idea that the change in the proportion of fish in the diet at Digges Sound is potentially long-term, and has trophic-level implications. Furthermore, if the changes in the diet of the murres have led to a change in their trophic position, then our results have implications for the interpretation of pollutant loads, as trophic level influences biomagnification of contaminants such as mercury, and murres are an important monitoring species in the Canadian Arctic (Braune 2009). 


\section{CONCLUSIONS}

With only 2 sampling periods to compare, changes in prey species need to be interpreted carefully, and more detailed sampling is needed to fully understand potential biodiversity changes in Arctic waters. However, the decrease in cold-water species across the low Arctic, along with the increase in capelin and mysids in the low and mid-Arctic, illustrates that the biota of these regions is undergoing dramatic changes.

The contrast between the changes in prey observed in the low Arctic and the much less dramatic changes in the diet of the murres in the mid-Arctic suggests that what has occurred in the low Arctic may represent a step-wise change in the marine ecosystem. While the low-Arctic areas in Hudson Bay seem to have shifted towards subarctic species over the last few years, the marine ecosystem of the midArctic appears to be at an Arctic-subarctic transition period, with sympagic species still present but with subarctic species such as capelin and sandlance now becoming regular components of seabird diets.

Overall, we see the greatest change in murre diet in the low Arctic and the least in the high Arctic, with the mid-Arctic showing an intermediate amount of change, as predicted. When this change is compared with sea ice data, the greatest change in diet, specifically in ice-associated prey species, coincides with those areas where sea ice has declined and is no longer present while murres are provisioning their chicks. In the mid-Arctic, where the sea ice is still present during the chick-rearing period, changes in prey species are already occurring, with capelin and sandlance now found at more northern latitudes than previously reported and now being consumed by the birds in quantities similar to those observed in the low Arctic 25 yr ago, suggesting that change will continue in this location if summer sea ice continues to decline. Along with razorbills Alca torda (Gaston \& Woo 2008) and great black-backed gulls Larus marinus (H. G. Gilchrist \& J. F. Provencher unpubl.), 2 subarctic marine birds, the movement of capelin to more northern latitudes adds to our knowledge of subarctic species that have become more common in low- and mid-Arctic areas. These changes may have several different effects on the murre colonies of the Arctic Archipelago, and continued work in monitoring of populations will help detect long-term changes in this important human-hunted species.

Studying murres in the Canadian Arctic provides significant and relevant information on changes in the availability of a number of fish and invertebrate species where little or no other fisheries-assessment work is currently being done. The murre colonies in the eastern Canadian Arctic, where long-term studies have been established, are strategic study locations where continued monitoring will allow us to track potential changes in seabird populations and their prey species as changing climatic conditions continue to be observed.

Acknowledgements. We thank M. Mallory, S. Smith, P. Smith, I. Storm, S. Suppa, and J. Szucs for help collecting the specimens; G. Savard, S. Robinson, and students from Nunavut Arctic College for assistance with dissections; and J. Dower (University of Victoria) for providing space and equipment for our use through his Natural Sciences and Engineering Research Council of Canada (NSERC) strategic funding grant. Scientific studies and collections were conducted in accordance with guidelines from the Canadian Council on Animal Care, and under appropriate territorial and federal research permits. Financial and logistic support was provided by NSERC, Environment Canada, Natural Resources Canada (Polar Continental Shelf Project), the Nattivak Hunters' and Trappers' Organization, and International Polar Year 2007-2009. We also thank the Institute of Ocean Sciences (Department of Fisheries and Oceans Canada) for in-kind support to P.D.O.

\section{LITERATURE CITED}

Audzijonyte A, Vainola R (2007) Mysis nordenskioldi n. sp (Crustacea, Mysida), a circumpolar coastal mysid separated from the NE Pacific M. litoralis (Banner, 1948). Polar Biol 30:1137-1157

Baker AC, Boden BP, Brinton E (1990) A practical guide to the euphausiids of the world. The Natural History Museum, London

Barber DG, Lukovich JV, Keogak J, Baryluk S, Fortier L, Henry GHR (2008) The changing climate of the Arctic. Arctic 61:7-26

> Bradstreet MSW (1980) Thick-billed murres and black guillemots in the Barrow Strait area, N.W.T., during spring: diets and food availability along ice edges. Can J Zool 58:2120-2140

Braune BM (2009) Effects of climate change on diet and contaminant exposure in seabirds breeding in northern Hudson Bay. Northern Contaminant Program, Indian and Northern Affairs Canada, Ottawa

Brekke B, Gabrielsen G (1994) Assimilation efficiency of adult kittiwakes and Brunnich's guillemots fed capelin and Arctic cod. Polar Biol 14:279-284

Brown RGB, Nettleship DN, Germain P, Tull E, Davis T (1975) Atlas of eastern Canadian seabirds. Canadian Wildlife Service, Ottawa

Cairns DK (1987) Seabirds as indicators of marine food supplies. Biol Oceanogr 5:261-271

Campana SE (2004) Photographic atlas of fish otoliths of the Northwest Atlantic oceans. National Research Council Canada, Ottawa

Cheung WWL, Lam VWY, Sarmiento JL, Kearney K, Watson R, Pauly D (2009) Projecting global marine biodiversity impacts under climate change scenarios. Fish Fish 10: $235-251$ 
Clarke MR (1962) The identification of cephalopod 'beaks' and the relationship between beak size and total body weight. Bull Br Mus (Nat Hist) Zool 8:419-480

Craig PC, Griffiths WB, Haldorson L, McElderry H (1982) Ecological studies of Arctic cod (Boreogadus saida) in Beaufort Sea coastal waters, Alaska. Can J Fish Aquat Sci 39:395-406

Davoren GK, Montevecchi WA (2003) Signals from seabirds indicate changing biology of capelin stocks. Mar Ecol Prog Ser 258:253-261

Edwards M, Richardson A (2004) Impact of climate change on marine pelagic phenology and trophic mismatch. Nature 430:881-884

Elliott KH, Woo KJ, Gaston AJ (2009) Specialization in murres: the story of eight specialists. Waterbirds 32:491-506

Gaston AJ (1991) Seabirds of Hudson Bay, Hudson Strait and adjacent waters. In: Croxall JP (ed) Seabird status and conservation: a supplement. International Council for Bird Conservation, Cambridge, p 7-16

> Gaston AJ, Bradstreet MSW (1993) Intercolony differences in the summer diet of thick-billed murres in the eastern Canadian Arctic. Can J Zool 71:1831-1840

Gaston AJ, Nettleship DN (1981) The thick-billed murres of Prince Leopold Island. Environment Canada, Ottawa

Gaston AJ, Noble D (1985) The diet of thick-billed murres (Uria lomvia) in west Hudson Strait and northeast Hudson Bay. Can J Zool 63:1148-1160

Gaston AJ, Smith SA (1987) Seabirds in the Cape Dyer Reid Bay area of Cumberland Peninsula, Northwest Territories. Can Field-Nat 101:49-55

Gaston AJ, Woo K (2008) Razorbills (Alca torda) follow subarctic prey into the Canadian Arctic: colonization results from climate change? Auk 125:939-942

Gaston AJ, Cairns DK, Elliot RD, Noble DG (1986) A natural history of Digges Sound. Can Wildl Serv Rep Ser 46

Gaston AJ, Woo K, Hipfner JM (2003) Trends in forage fish populations in northern Hudson Bay since 1981, as determined from the diet of nestling thick-billed murres Uria lomvia. Arctic 56:227-233

Gaston AJ, Gilchrist HG, Mallory ML (2005a) Variation in ice conditions has strong effects on the breeding of marine birds at Prince Leopold Island, Nunavut. Ecography 28:331-344

Gaston AJ, Gilchrist HG, Hipfner JM (2005b) Climate change, ice conditions and reproduction in an Arctic nesting marine bird: Brunnich's guillemot (Uria lomvia L.). J Anim Ecol 74:832-841

Gaston AJ, Bertram DF, Boyne AW, Chardine JW and others (2009) Changes in Canadian seabird populations and ecology since 1970 in relation to changes in oceanography and food webs. Environ Rev 17:267-286

Gotelli NJ, Colwell RK (2001) Quantifying biodiversity: procedures and pitfalls in the measurement and comparison of species richness. Ecol Lett 4:379-391

Gotelli N, Entsminger G (2009) EcoSim: null models soft- ware for ecology, version 7. Acquired Intelligence \& Kesey-Bear, Jericho, VT

- Hawkins PAJ, Butler PJ, Woakes AJ, Gabrielsen G (1997) Heat increment of feeding in Brunnich's guillemot Uria lomvia. J Exp Biol 200:1757-1763

Holmquist C (1959) Problems on marine-glacial relicts on account of investigations on the genus Mysis. Berlingska and Boktryckeriet, Lund

Horner R, Ackley SF, Dieckmann GS, Gulliksen B and others (1992) Ecology of sea ice biota 1. Habitat, terminology, and methodology. Polar Biol 12:417-427

IPCC (Intergovernmental Panel on Climate Change) (2007) Climate change 2007: the physical science basis. Summary for policymakers. Cambridge University Press, Cambridge

Jackson S, Ryan PG (1986) Differential digestion rates of prey by white-chinned petrels (Procellaris aequinoctialis). Auk 103:617-619

Klekowski RZ, Weslawski JM (eds) (1991) Atlas of the marine fauna of southern Spitsbergen, Vol 2. Institute of Oceanography, Gdansk

Leim A, Scott W (1966) Fishes of the Atlantic coast of Canada, Vol 155. Fisheries Research Board of Canada, Ottawa

Muss BJ, Nielsen JG, Dahlstrom P, Nystrom BO (1999) Sea fish. Scandinavian Fishing Year Book, Hedehusene

$>$ Piatt JF, Sydeman WJ, Wiese F (2007) A modern role for seabirds as indicators. Mar Ecol Prog Ser 352:199-204

Rekacewicz P, Bournay E (1998) Surface currents in Hudson Bay, Hudson Strait and Foxe Basin. In: AMAP assessment report: Arctic pollution issues. Arctic Monitoring and Assessment Programme (AMAP), Oslo

Salomonsen F (1965) Geographical variation of fulmar (Fulmarus glacialis) and zones of marine environment in the North Atlantic. Auk 82:327-355

Scott JBT, Marshall GJ (2010) A step-change in the date of sea-ice breakup in western Hudson Bay. Arctic 63: 155-164

Soreide JE, Leu E, Berge J, Graeve M, Falk-Petersen S (2010) Timing of blooms, algal food quality and Calanus glacialis reproduction and growth in a changing Arctic. Glob Change Biol 16:3154-3163

Tee-van J (ed) (1948) Fishes of the western North Atlantic, Vol 3. Yale University, New Haven, CT

Tencati JR, Leung YM (1970) Taxonomic guides to Arctic zooplankton (I): amphipods of the central Arctic and euphausiids of the Arctic basin and peripheral seas. Department of Biological Sciences, University of Southern California, Los Angeles, CA

Tuck LM, Squires HJ (1955) Food and feeding habits of Brunnich's murre (Uria lomvia lomvia) on Akpatok Island. J Fish Res Board Can 12:781-792

Vinogradov M, Volkov A, Semenova T (1996) Hyperiid amphipods (Amphipoda, Hyperiidea) of the world's oceans. Smithsonian Institution Libraries, Washington, DC 